\title{
8 Unitary state, devolution, autonomy, secession: state building and nation building in Bougainville, Papua New Guinea
}

\author{
Yash Ghai and Anthony J. Regan
}

\section{SCENE SETTING}

There are often difficulties in accommodating the interests of minority nationalities within nation-states. The proliferation of states created by decolonization has magnified such problems. Colonial borders often included groups with emerging identities, and the problems of fostering national cohesion within borders encompassing such diversity has sometimes been especially intense.

Various forms of federalist and similar arrangements for the territorial distribution of power have been employed in efforts to accommodate the concerns of ethnic and other identity groups (Watts, 1999; Ghai, 2000; 2002a). Implementation and operation of such arrangements can be far from easy in postcolonial states, where capacity and resources are often limited. Pressures for asymmetrical arrangements for nationalist minorities can magnify such problems, as they tend to be seen as "an incentive for spiralling devolution, fuelling secession, catalysing the eventual implosion of the state" (Baldacchino, 2006).

Island sub-national jurisdictions offer an instructive distinct category for examining the ways in which tensions between nation-states and sub-national units are managed (Baldacchino, 2006). Indeed, as Baldacchino points out, islands represent "quintessential platforms for nation states... [as] finite island geography smoothens the nurturing of a sense of identity that is contiguous with territory" (Baldacchino, 2006), a perception that would raise expectations of pressure for nation-state status on the part of non-sovereign island territories.

In fact, over the past 20 years that has not been happening - most sub-national island autonomies have not been seeking nation-state status. McElroy and Mahoney (1999) suggest that in large part this is because there are substantial economic advantages to small non-sovereign island units remaining part of a larger state. Many island autonomies have developed innovative economic policy and governance practices that enable them to escape the economic vulnerability that would tend to go together with either full sovereignty or the absence of autonomy (Baldacchino, 2004). The economic practices involve powers over key aspects of finance; natural resources; access (through transport); free movement of persons; and tourism policy. The creative political practices involve high levels of jurisdictional prerogative; articulation of national identity; defence and promotion of minority rights; and paradiplomacy. Through use of such devices, asserts Baldacchino, island autonomies can develop high standards of living and levels of self-rule, the outcome being that "there hardly appears to be any sentiment for independence among non-sovereign island 
territories today... [and while] there are a number of peoples waiting in the proverbial wings to declare their statehood... only one of these is an island" (Baldacchino, 2004, p. 78)

That exception is Bougainville, a reluctant part of the southwest Pacific state of Papua New Guinea (PNG). If other secessionist situations, such as the Indonesian examples of Papua and Aceh, and the Philippines case of Mindanao, are also classified as non-sovereign island territories, then the detail of Baldacchino's classification can be contested, but not his basic point about the tendency of many such territories to explore innovative alternatives to secession. The question then arises as to why Bougainville and other island secessionist cases are not also exploring such alternative strategies. One factor that may be of significance is that, unlike many of the island autonomies considered by Baldacchino, Bougainville and the other divergent cases just mentioned do not involve autonomy arising from a colonial relationship (as, for example, with the former colonial territories of New Zealand and the USA or the continuing Pacific island colonial territories of France). It is in the special circumstances of making choices about the management of continuing or modifying such relationships that the autonomy arrangements and the innovative strategies have developed.

In the Bougainville case nationalism was first asserted in the years leading to PNG's 1975 independence from Australia (Griffin, 1972; 1973; Mamak and Bedford, 1974). The emergence of several 'micro-nationalist' movements (May, 1982), including one in Bougainville, was among the complex factors that had to be taken into account in making choices for PNG's independence constitution. PNG had a weak state and fragile administration and no national identity to help foster national cohesion. Its constitution would have to deal with both state building and nation building. But how was this to be done?

This chapter examines the tensions between various approaches used since PNG's independence in efforts to respond to minority nationalist pressures, the initial choice being between a unitary state and a devolved state with substantial self-government for territorially based communities. The particular focus is Bougainville, the one part of PNG where sub-national identity has not been accommodated by devolution. Rather, there have been two secession attempts, one in 1975 and the other from 1988 to 1989 as part of a bitter and bloody civil war. The latter conflict was settled in 2001 only by PNG agreeing to both asymmetrical autonomy and keeping open the possibility of independence through a constitutionally guaranteed but deferred referendum on the issue. The autonomy arrangements have been in their early stages of implementation since 2006.

The analysis addresses the vexed question of whether asymmetrical autonomy, in particular, inevitably creates pressure for progress towards independence. It also considers the extent to which the economic policy and governance practices identified by Baldacchino have been available to and used by Bougainville.

\section{PNG AND BOUGAINVILLE}

Bougainville is an island autonomy within a nation-state comprising half of one of the world's largest islands, and thousands of other islands of various sizes. The PNG 'mainland' consists of the eastern half of New Guinea and, to the east, includes the 
three large islands of New Britain, New Ireland and Bougainville, each with numerous associated small islands. With well over 800 distinct languages, PNG is a country of unparalleled linguistic and cultural diversity. Bougainville's roughly 200000 people (about $4 \%$ of PNG's population of more than five million) reflect that same diversity, speaking 25 distinct languages and many more sub-languages and dialects (Tryon, 2005).

PNG is a creation of the late colonial era. The UK and Germany took control of the southern (Papua) and northern (German New Guinea) parts, respectively, in 1884. Australia assumed control of Papua in 1906, and ousted Germany from New Guinea at the beginning of World War I, later taking a League of Nations mandate over the former German territory, including Bougainville. Papua and New Guinea were administered jointly only from 1946 until PNG's independence in September 1975. Governing through a highly centralized, bureaucratic system (Tordoff and Watts, 1974; CPC, 1974; Conyers, 1976), Australia had limited objectives (largely concerned with its own security and extraction of some resources). Large parts of the territory remained almost untouched by either colonial administration or the market until the late colonial period, Christian missions bringing more change to the lives of perhaps most communities than either state or market. Pre-colonial social structures persisted, most people living in groups of no more than a few hundred. Internal communications were poor, there was little mobility of people or goods, and little political or economic integration. Thus, little sense of a common identity developed among PNG's disparate communities.

Bougainville is a group of islands about 1000 kilometres east of the mainland PNG capital of Port Moresby, close to the western islands of the neighbouring country of Solomon Islands, with whose inhabitants the islanders share appearance, language groups and culture. The two main islands are Bougainville and the much smaller Buka, separated by a narrow sea passage. Cultural and linguistic differences and uneven development during and after the colonial era have been among factors contributing to differing identities and economic interests among Bougainvilleans. In particular, many groups in Buka and on the east coast of Bougainville adjacent to the colonial administrative centre and plantations have had much greater access than others to education, employment and opportunities for economic advancement, a source of inequality that contributes to tensions and divisions (Ogan, 1996; Nash, 2001; Regan, 2005b; Tanis, 2005). On the other hand, a sense of identity separate from the rest of PNG emerged during the twentieth century, the primary marker being the distinctive very dark skin colour of most Bougainvilleans (Griffin, 1972; 1973; Mamak and Bedford, 1974; Nash and Ogan, 1990; Oliver, 1991).

Identity was politicized by grievances about colonial neglect, compounded by the imposition by the Australian colonial administration of the operationalization by Bougainville Copper Ltd (BCL) of one of the world's largest copper and gold mines at Panguna in central Bougainville (Bedford and Mamak, 1977; Connell, 1991; Oliver, 1991; Regan, 1998a; 2003; Denoon, 2000). Bougainvilleans perceived the mine as being established for the economic benefit of the rest of PNG, with Bougainville carrying the social and environmental costs, but receiving little mine revenue. BCL's total earnings in its 17 years of operation (April 1972 to May 1989) were US\$4.6 billion, which generated $\$ 1.9$ billion in revenue, of which just $5.63 \%$ went to Bougainville: $4.27 \%$ (mostly mineral royalties) to Bougainville's provincial government (see below) and $1.36 \%$ to Bougainvillean owners of land leased for mining 
purposes (rents, compensation and a small share of royalty payments) (Connell, 1991; Quodling, 1991, p. 55; Regan, 2003, p. 139).

From the late 1960s, with PNG's independence from Australia approaching, there was growing talk in Bougainville of possible independence from PNG (Griffin, 1972; 1973; Ghai and Regan, 2000, pp. 244-247). Educated leaders mainly used talk of independence in efforts to mobilize support for more modest goals of autonomy and increased mining revenue. Yet, in the process, many Bougainvilleans increasingly saw independence as a solution to a wide range of social problems, and as a real possibility.

\section{A UNITARY OR A DEVOLVED STATE?}

In the lead-up to an independence resulting more from Australian responses to emerging international pressure than from internal demands, people in some areas of PNG sought a significant degree of autonomy from the unknown emerging state through local organizations and institutions (Conyers, 1976; Ballard, 1981; May, 1982). Nowhere was the demand for local autonomy stronger than in Bougainville.

At the same time there was strong support for the opposing view that PNG's diversity would best be kept unified through a continuation of the unitary arrangements of the colonial state. This approach was preferred by the departing colonial regime and key leaders of PNG's first indigenous government, in power after the last election to the colonial legislature (1972), and with self-governing status from 1973.

In the independence constitution-making process $(1972-75)$, two contrary paradigms emerged, each claiming to be best suited to the needs of building national identity and unity. ${ }^{1}$ The main support for the local autonomy approach came from the Constitutional Planning Committee (CPC), a committee of the colonial legislature under the leadership of a young member of the legislature from Bougainville, John Momis. The CPC developed proposals for the independence constitution presented in a long and detailed report in mid-1974 (CPC, 1974). It saw local autonomy as both accommodating ethnic identity (thereby contributing to national unity) and improving the efficiency and responsiveness of the hitherto inefficient centralized colonial state by encouraging popular participation (Wolfers et al., 1982, p. 286; Ghai and Regan, 1992, pp. 8-52; Ballard, 1981). The CPC was in part responding to pressure from Bougainville (Griffin et al., 1979; Ballard, 1981; Ghai and Regan, 1992), where from 1973 the national government reluctantly conceded limited autonomy by recognizing a Bougainville Interim Provincial Government.

No one seriously pushed for federalism, however, largely because there were no strong ethnic or territorial groupings - other than Bougainville - demanding territorial autonomy. Yet the CPC's conceptualization of devolution entrenched in the constitution came close to a form of quasi-federalism. ${ }^{2}$

After initial ambivalence the government, under Chief Minister Michael Somare, ultimately opposed the CPC proposals (on the grounds of unity, efficiency and economic rationality) and in July 1975 persuaded the colonial legislature (sitting as a constituent assembly) to reject them (Conyers, 1976; Ballard, 1981; Ghai and Regan, 1992). This precipitated a major crisis in Bougainville. The choice between a unitary or a devolved state thus emerged as the most contentious constitutional issue. 
On the rejection of constitutionally protected devolution Bougainville declared its separate independence from PNG on 1 September 1975, days before PNG's Independence Day. Failure to secure international recognition and concern about dangers of violence encouraged Bougainville leaders to negotiate, with John Momis (who resigned from the national legislature in support of Bougainville secession) playing a moderating role (Ballard, 1981; Griffin and Togolo, 1997; Momis, 2005, pp. 312-314). A central government under its first prime minister, Michael Somare, who knew John Momis well, was both conscious of the risk of other areas in the fragile new nation following Bougainville's example and concerned about possible loss of revenue from the mine. It was thus also under pressure to resolve its differences with Bougainville. Six months of negotiations concluded with an August 1976 agreement on constitutionally entrenched autonomy arrangements for Bougainville. A major question, however, was whether autonomy should be asymmetrical - with many powers and resources reserved to Bougainville - or symmetrical, with arrangements negotiated by Bougainville being extended to PNG's other 18 provinces.

Even in the lead-up to independence there had been concern that special arrangements for Bougainville would be divisive for PNG, and the concessions towards autonomy secured by Bougainville had been generalized to other provinces (Conyers, 1976; Ballard, 1981; Ghai and Regan, 1992). However, in 1976 the negotiations were truly bilateral, and Bougainville argued for special arrangements. PNG's negotiators were initially open to the proposal and as a result conceded significantly greater provincial powers than would otherwise have been the case. But, as final details were negotiated, fears of special arrangements being divisive again dominated, and PNG reserved the right to extend the concessions to all the provinces. Bougainville agreed reluctantly, mainly because of awareness that amendments to the national constitution would require a high degree of support in parliament, where representation was still seen in provincial terms.

In the end the constitutional amendment provided for an almost completely uniform system of devolution. The main exception involved distribution of mining royalties that in practice applied only in Bougainville (at least until other major mines began to operate elsewhere in PNG from 1984) (Axline, 1986; Ghai and Regan, 1992, pp. 234-259). This ensured a unique degree of fiscal independence for the North Solomons Provincial Government (NSPG) - a name chosen to emphasize Bougainville's links to communities in the neighbouring country of Solomon Islands.

The devolution arrangements were even more quasi-federal than the original CPC proposals on which they drew. The legal provisions were contained in the constitution, in the form of principles, with an organic law (the Organic Law on Provincial Government) setting out details. Organic laws are as difficult to amend or repeal as the constitution, and so devolution enjoyed considerable legal protection.

The Organic Law distributed legislative powers through two lists (Ghai and Regan, 1992, pp. 33-38,135-194): a short one of 'primarily' provincial subjects and a long one of concurrent powers. In the former, provincial laws prevailed over national laws, which could be made only if a province had not made an exhaustive law on a subject in this list. For concurrent subjects, national law prevailed over provincial law, but national laws could be made only on a matter 'of national interest' and 'to the extent 
that the matter is of national interest'. Another principle qualified the scope of national laws on concurrent subjects. Since, at the start of devolution, there were national laws on most such subjects, a provincial government desiring to make a law in a field occupied by national law could request repeal of national government law in relation to the province to the extent necessary to permit provincial law to be made on matters of provincial interest. The presumption was that the national government would oblige, unless there was a pressing national interest in having central legislation on the subject. Subjects not listed stayed with the national government. Thus the system, while maintaining the ultimate authority of one or the other level of government in respect of every subject, was intended to provide considerable flexibility.

Provincial government structures (Ghai and Regan, 1992, pp. 77-134) were required to meet basic criteria set out in the Organic Law - notably an elected legislature - but some latitude in choice of structures was provided for in provincial constitutions made through consultative processes. The effective working of the complex provisions for fiscal arrangements (guaranteed grants and some exclusively provincial taxes), the allocation of legislative authority and the division of administrative powers and staff were all intended to depend on cooperation between governments. Such cooperation was to be secured through basic principles and procedures (such as the obligation of a government at one level to give notice to government/s at the other level of its legislative proposals, and a general obligation for consultation), and through intergovernmental institutions. The Premiers' Council was the main institution. Bringing together the prime minister and senior ministers with premiers of provinces, its primary function was to discuss fiscal policies and transfers, legislative powers of provinces, intergovernmental cooperation and the resolution of disputes. To avoid excessive legalism, disputes had to be resolved through negotiations or mediation, if possible, before they could be taken to a court.

This description comes close to a model of cooperative federalism or devolution. Within broad principles it provided a framework for continuing negotiations, especially on the gradual transfer of powers from the centre under the two legislative lists, and on the allocation of resources. It put a premium on trust and good faith; but also on capacity to handle complex institutions and negotiations.

Implementation started well, with considerable support from the national government. Popular consultation to prepare provincial constitutions heightened a consciousness of a common identity and future. The pace was set by Bougainville, whose leaders brought great energy and planning to developing the NSPG. Tensions between the national government and provinces keen on autonomy (including Bougainville) seemed to be getting resolved. By 1979 all 19 provincial governments had been established (Ghai and Regan, 1992, pp. 49-75). Devolution seemed to have transformed, constructively, the PNG political scene. State building and nation building appeared indeed to go hand in hand.

But this rosy picture did not last, the most critical reason being that the intended fluidity of political power gave way to the reality of consolidation of the central state apparatus (Ghai, 1997; Ghai and Regan, 1992; 2001). The dominant position of the state in relation to the PNG economy meant that political and bureaucratic access to the state was the main means of accumulation of wealth. The central state remained the primary site of power, attracting most leading politicians. But at the same time national politicians resented the competition for powers and resources from provincial leaders. Moreover, few provincial governments operated effectively and 
they thus failed to mobilize strong popular support (Ghai and Regan, 2000). Nor were provincial governments able to cooperate effectively through the intergovernmental mechanisms to apply pressure to the national government to transfer increasing powers and resources. More importantly, capacity for policy and administration was weak at all levels of government (in large part because of the failure of the Australian colonial administration to develop an educated elite). Provincial governments made little use of the legislative powers available to them. Resources of most provincial governments decreased rather than increased.

By the early 1980 s relations between the national government and provincial governments were often strained. The national government paid little more than lip service to aspects of the machinery that it could not ignore. Arrangements for suspension of provincial governments were amended in 1983, removing important procedural safeguards against abuse. Those powers were subsequently used extensively against provincial governments and often for purely political reasons.

The NSPG was one of few exceptions to the gloomy picture (Ghai and Regan, 1992; Griffin and Togolo, 1997), with its strong base in community support mobilized by the identity politics of the 1970 s and its comparatively strong revenue base. In the 1970s the central priorities of Bougainville's elite leadership had been to achieve autonomy and a share of mining revenue. The 1976 decentralization arrangements and the economic opportunities available to them ensured that members of the elite were accommodated. Hence the NSPG could manage relations with the national government within the framework of the constitutional arrangements, admittedly with some tensions. For the most part it was fully occupied with maintaining basic services, managing its capital expenditure programme and gradually building capacity from the very weak local base left by the centralized colonial administration. Until the early to mid-1980s it was unable to put much effort into developing its own policies (Ghai and Regan, 2000).

In terms of the kinds of innovative strategies used by island autonomies to bolster their positions vis-à-vis the central government, the creative political capacities identified by Baldacchino (2006) were not readily available to Bougainville. It did not already have established high levels of jurisdictional prerogative, and was instead gradually working to develop these. It was still in the early stages of articulation of national identity. The defence and promotion of minority rights was not a strategy readily available in PNG, where all language and culture groups are small minorities. Para-diplomacy had not been developed. Much the same was true of the five economic strategies highlighted by Baldacchino (Baldacchino, 2006), in large part because the powers of the NSPG under the constitutional devolution arrangements were quite limited. It did not have control of key aspects of finance, such as banking and insurance, and had limited tax powers. It had virtually no control over land and natural resources policy. It did not control access through power over transport. It had almost no control over movement of persons, and so could not control the influx of large numbers of persons from elsewhere in PNG, attracted by economic opportunities in Bougainville, often squatting on customary land. The many outsiders were seen by Bougainvilleans as both undermining their traditional authority and culture, and a major contributing factor to growing law and order problems. Mining and agriculture being the major economic sectors, tourism was not a major concern in Bougainville. Overall, the NSPG had limited power to respond to the ongoing tensions associated with the unresolved grievances of ordinary people over the 
impacts of the mine and the influx of outsiders, something that was a contributing factor to the violent conflict that developed in 1988-89 (Regan, 1998a, 1998b; Premdas, 1998; Ghai and Regan, 2000; Kauona, 2001; Tanis, 2005).

\section{CONFLICT AND PEACE PROCESS, 1988-2001}

Neither the NSPG nor the national government expected that such tensions would contribute to a civil war in Bougainville from late $1988 .{ }^{4}$ The conflict was precipitated by inter-generational disputes within communities owning land where the mine was located over distribution of mine revenues payable to landowners. Frustration on the part of younger landowners with links to disgruntled Bougainvillean mine workers led to destruction of mine property. Mainly intended to create pressure for increased benefits, this action instead led to generalized violent responses by PNG forces. This violence acted as a catalyst for a broader rebellion led by a key figure among the younger mine lease landowners, Francis Ona. Had the NSPG wielded power over land and mining, and possessed some ability to limit squatting on customary land by outsiders, the situation would probably have developed quite differently. But, as the rebellion gathered force in 1979, the NSPG, led by Joseph Kabui, the young premier from the mine lease area with close relationships with many of the leaders of the rebellion, was in a difficult position, suspected by both the national government and the rebels.

Political support for secession was mobilized around both the long-held Bougainvillean grievances concerning the mine and Bougainvillean identity. However, the secessionist leadership, having made a unilateral declaration of independence soon after the withdrawal of PNG forces from Bougainville in March 1990, largely lost control of the situation soon after that, as internal Bougainville conflict undermined what would have otherwise been fairly broad support for secession. It was both civil war among Bougainvilleans and the fight between the pro-secessionist Bougainvillean faction and the national government that resulted in heavy loss of life and property, the breakdown of essential services, economic stagnation, missed educational opportunities for a whole generation, and the destruction of most of the impressive capacity of the provincial administration developed since the mid-1970s. The NSPG was suspended by the national government from mid-1990.

It would take too long to recite the causes and course of the complex conflict and its ending through a remarkable peace process beginning in mid-1997..$^{5}$ Rather, we have to jump to late 1998 , when, active fighting having ceased, rival Bougainville factions began talks on reconciliation and resolving their differences. One faction was led by Joseph Kabui, who in the early 1990s had become the deputy to the rebel leader, Francis Ona. It advocated secession. The other faction, a coalition of groups supporting stronger autonomy within PNG, was led by John Momis, back in the national parliament ever since 1977 . There was a third faction under Ona that refused to join the peace process, claiming that independence had already been achieved in 1990, but this group had limited popular support.

The compromise reached in advance of negotiations with PNG beginning in June 1999 involved those supporting independence dropping their demands for early independence and instead agreeing to deal with that issue through a referendum among Bougainvilleans on the question, but deferred to allow time for divided 
Bougainvilleans to reconcile (Regan, 2002c). On the basis that those favouring integration would agree to back the holding of the referendum, the secessionists agreed to support the high autonomy for Bougainville preferred by the integrationists, a level of autonomy greatly in advance of the 1976 arrangements.

This latter demand alone was a strong call, for by now PNG had effectively dismantled the 1976 devolution scheme, with provinces having much reduced (and uniform) autonomy (May, 1997; 1999). From 1995 elected provincial governments had been replaced by bodies made up of members of the national legislature from the provinces, together with heads of local-level government, all holding provincial office ex officio. In large part the reform was possible because the provincial government in Bougainville, the area of strongest support for devolution, was suspended, and Bougainville embroiled in civil war (Ghai and Regan, 2000).

But the Bougainvilleans were in a strong negotiating position throughout the two years of talks that produced the Bougainville Peace Agreement of August 2001. The secessionists had held the upper hand militarily when the fighting ended in 1997, and retained arms and the capacity for disruption. Further, while the dissident Ona faction had limited support, its refusal to join the process limited the scope for compromise on the part of the Bougainville side to the negotiations, and added to the pressure on the PNG side. The nine years of conflict had involved a high cost for PNG in terms of impacts on the economy, damage to morale in the police and the army, and undermining the country's international human rights reputation. PNG was also under considerable international pressure to settle the conflict for purposes of regional stability. Moreover, it realized that the strong sense of grievance in Bougainville concerning the conflict required substantial concessions to be made if the conflict was to be resolved. It was also anxious to disarm the factions and remove weapons.

Agreement was reached on enhanced autonomy only by PNG conceding that the issue of independence would be kept alive and revisited through a referendum for Bougainvilleans on Bougainville's independence deferred for a minimum of 10 years and a maximum of 15 years after establishing the autonomous government for Bougainville. Both referendum and autonomy would be constitutionally guaranteed, provided arms held by the Bougainville factions were disposed of.

This time, the clear intention was that the new autonomy arrangements would apply only to Bougainville, which now therefore has a special status in the country: an asymmetry that may in turn spawn its own problems. But, for the time being, sufficient consensus was developed in the national cabinet and parliament for the extensive amendments to the national constitution to incorporate the 2001 Peace Agreement to be enacted early in 2002. In other ways too, considerable progress has been made towards its implementation.

\section{ASYMMETRICAL AUTONOMY AND THE POSSIBILITY OF INDEPENDENCE, 2001 TO THE PRESENT}

As with the 1976 arrangements, large parts of the 2001 Peace Agreement have been implemented through amendments to the national constitution and an Organic Law on Peace-building in Bougainville - Autonomous Bougainville Government and Bougainville Referendum. These provisions cannot be amended by the PNG parliament without agreement by the Bougainville legislature. 
As for the nature of the enhanced autonomy now available to Bougainville, we can highlight here just a few aspects that enable comparisons with features of the 1976 arrangements summarized earlier. Only a small list of legislative powers in relation to Bougainville is reserved to the national government. Further, in the exercise of some of its powers (such as defence, foreign affairs and law and order), PNG is obliged to consult with Bougainville and to encourage its participation when Bougainville interests might be involved. In foreign affairs, for example, PNG may authorize Bougainville to enter into treaties with other states, and to have independent participation in international cultural or sporting activities. A long list of powers is made available to Bougainville, on an exclusive basis, which includes most subject areas likely to be covered by law, including power to establish a judiciary (subject to the ultimate appellate powers of the PNG Supreme Court), a public service and a police force. Bougainville has the right to initiate the process of transfer of powers from the national government by giving 12 months' notice, following which the two governments are required to cooperate to enable Bougainville to develop the capacity needed to exercise the power.

The financial arrangements do not, however, guarantee as much to Bougainville as did the 1976 arrangements, reflecting both the fiscal crisis facing the PNG government since the mid-1990s and the absence of mine revenues in Bougainville (the Panguna mine not having operated since 1989). On the other hand, autonomy is far higher in terms of both choice of Bougainville government structures and intergovernmental relations.

Concerning government structures, Bougainville now has its own constitution, drafted and adopted on behalf of its people by broadly representative bodies - a Bougainville Constitutional Commission and a Bougainville Constituent Assembly and endorsed by PNG in December 2004. As authorized by the 2001 Peace Agreement and the PNG constitutional provisions implementing it, the Bougainville Constitution contains Bougainvilleans' choice of names for their government (Autonomous Bougainville Government - $\mathrm{ABG}$ ) and for Bougainville (the Autonomous Region of Bougainville), both choices emphasizing a unique status, distinct from the provinces elsewhere in PNG. It also establishes an elected legislature, including three seats each reserved for women and former combatants. The ABG executive is headed by a directly elected president. Provision is made for a range of processes directed towards encouraging both accountability and close relations between the new government and the holders of customary authority in Bougainville society, and for a range of new institutions, most to be established in the future, when funding resources become available.

As for intergovernmental relations, a joint supervisory body with equal representation of both governments is responsible for overseeing the implementation of the autonomy arrangements and for being the first formal stage of a dispute settlement process. In contrast to the subordination of provinces to the centre under the previous system, powers to suspend provincial governments or withdraw powers from them do not apply to Bougainville, a major move towards a coordinate status.

It was possible to sell autonomy to Bougainville precisely because the 2001 agreement kept alive the option of secession through the provision for a deferred referendum. The reluctant acceptance by the national government of the referendum provisions was facilitated by the manner in which provision on the subject was hedged in the agreement. The referendum can be held only after specified conditions 
are met (weapons disposal achieved and good governance established and maintained). The Bougainville government can decide after all not to have a referendum, after consultation with the national government and by decision made in accordance with a process set out in the Bougainville Constitution (although the special majorities and consultative procedures laid down in that constitution make it unlikely that such a decision will ever be made). But, most importantly, the outcome of the referendum will at best be advisory, for to be effective it has to be ratified by the national parliament. It is evident that these rules and restrictions could themselves be a cause of friction in the future; but for the time being they have secured peace.

The non-binding outcome of the referendum was contrary to the strong position of the Bougainvilleans for the first 18 months of the negotiations on political agreement. It was an issue on which they eventually compromised, under international pressure, in order to persuade the national government to agree to a constitutionally guaranteed referendum. They did so in the belief that, if they could unify Bougainvilleans and achieve a very high vote for independence, then, provided that the international community remained interested and involved, the PNG government would find it difficult to ignore the result. For its part the national government agreed not just because of international pressure, but also because it could argue that a nonbinding referendum did not undermine its sovereignty, and it would have 10 to 15 years to demonstrate to Bougainvilleans that it would be in their interests to vote against independence.

Although implementation of autonomy has occurred more slowly than expected, progress to date has been reasonable, but not without some strains on relations. Elections for the $A B G$ were held in mid-2005. The capacity of the ABG's administrative arm is weak, making the process of taking over the many powers and functions available to the ABG very slow. In terms of funding, the inherent logic of the combination of autonomy and a deferred referendum on independence suggests that the national government will make available the significant levels of funding needed to persuade Bougainvilleans to vote in favour of staying within PNG when the referendum is held (much as France has been doing in relation to New Caledonia). So far, however, funding for the $A B G$ from the national government in the first full year of autonomy has not been much more than the minimum. There are signs of the beginnings of frustration in the $A B G$, and increasing talk of allowing mining activity to resume as a way of ensuring that Bougainville has its own resources both to operate autonomy effectively and to provide the capacity needed for independence following the referendum. On the PNG side there are the beginnings of concern that the $A B G$ is being too confrontational in some of its dealings with the national government, and unreasonably pushing the limits of some aspects of autonomy, notably its competence to participate in international meetings in the region.

\section{ASSESSMENT AND REFLECTIONS}

Asymmetry begets complexity, but it also has a wider political significance. With the 2001 agreement Bougainville gains the prize that eluded it in 1976. Will it turn out to be a pyrrhic victory? Asymmetry seldom remains a bilateral matter between the asymmetrical unit and the centre. Others resent it for a variety of reasons. 


\section{Y. Ghai and A. J. Regan}

Asymmetrical arrangements have become a common feature of federal and autonomy arrangements in ethnically based societies. They facilitate the devolution of powers according to the circumstances of different regions and communities, but they tend to set the pace for others. They can also lead to complex arrangements, especially as the central government has to manage diverse relationships with different parts of the country. ${ }^{6}$ There was relatively little opposition to a special status for Bougainville this time round, with widespread recognition that special arrangements were needed in the interests of reconciliation and peace building.

Can this accommodation be sustained? If one goes by the experience of some other countries, one would have to accept that Bougainville asymmetry will most probably create tensions. Sometimes these tensions are managed by extending 'asymmetrical' relations to others - asymmetry is eliminated by enhanced autonomy for all (as happened in PNG in 1976). Pressure is already being applied by the East New Britain provincial government, which has a reasonable administrative record, seeking increased autonomy by drawing on the 2001 agreement (though taking care, so far, to indicate acceptance that peace building requires special arrangements for Bougainville). Would increasing pressures of this kind further loosen the structures of the state, making it harder for the centre, both at political and administrative levels, to manage centre-provincial relations?

What has devolution represented for PNG, and what will the enhanced autonomy do for Bougainville? Earlier we noted two impulses behind the original devolution proposals: accommodation of ethnic identity and participation intended to increase efficiency and responsiveness. Ethnicity has played a limited role elsewhere in PNG since independence (see, however, Larmour, 1990, 1992). This is perhaps because the very existence of numerous communities and identities dilutes the force of ethnicity; the ethnic base is often too slender to mobilize. It also means that the province is too large a unit for any one group to capture and dominate to make it the basis of ethnic identity. Perhaps cultural differences were not so substantial as to matter, at least politically. When we examine the purposes to which provinces put their powers under the 1976 arrangements, culture does not figure highly. In fact most provinces were not effective in mobilizing political support for provincial institutions, making it easy for the central government to repeal the 1976 arrangements in 1995.

Perhaps the lesson is that, while internal administrative boundaries can stimulate territorial identity, prior strong political or cultural consciousness is necessary for effective devolution. The role of provincial government could have been to foster provincial consciousness as part of nation building and, in the early days, particularly as people engaged in provincial constitution making, provincial identity seemed to be emerging (Ghai and Regan, 1992). But it seems not to have been sustained largely because the interests of some leading provincial personalities turned to national politics and most provincial governments were singularly inept at delivering material goods or political participation.

Is Bougainville, much given to the rhetoric of cultural identity, and where the conflict and the peace process have heightened a sense of distinct experience and identity, exceptional? Its 'islandness' and physical separation from the rest of the country, the distinctive appearance of its people and their proximity to Solomon Islands all emphasized Bougainvilleans' sense of uniqueness. But the conflicts with the rest of the country were not fundamentally ethnic. In 1976 they had more to do with 
the allocation of resources, particularly mining revenue. In 1989 mining revenue was still a major factor in an extraordinarily complex situation which worsened into armed conflict in part because of internal Bougainville differences, as well as of dissent from central government policies (some of the strongest champions of devolution, in the form of provincial government, were Bougainvilleans). But the dynamics of the conflict enhanced a distinction between 'us' (Bougainvilleans) and 'them' (other Papua New Guineans). Autonomy is now seen as providing an opportunity for Bougainvilleans to further develop their own identity (Bougainville Peace Agreement, 2001, para. 4). It is yet to be seen if the experience will be significantly different from that under the 1976 Agreement. While the terms of both the 2001 Peace Agreement and the new Bougainville Constitution suggest that the Bougainvilleans are much more ambitious the second time round, it is ironic that, without mine revenues, the resources available to develop autonomy will be much less.

What light does this PNG history throw on the claim that devolution/federalism is the first step to secession (often the strongest argument against autonomy)? At first glance, Bougainville's experiences seem to substantiate the claim. It could be argued that, having obtained limited autonomy in 1976 (by the 'threat' of the loss of mining revenue), it used that autonomy to raise the stakes, and then in 1989 by force of arms demanded secession, settling temporarily for enhanced autonomy only by winning the option of independence. We believe that this is a misreading. After the 1976 autonomy Bougainville leaders established an effective government in accordance with national laws, and played a full role in national politics. The 1989 troubles in large part had a common source to those of the mid-1970s - the inequitable distribution of the income from the copper mine - but this time it was initially not a province-wide protest. Rather, it originated in internal disputes among mine-lease landowner communities over distribution of mine revenues. It was the violent responses of the PNG forces that wrongly assumed a broad-based rebellion, which enabled a broader Bougainvillean mobilization round ethnic identity. But that rebellion was opposed by some other Bougainvilleans, even in its early stages (Togolo, 2005), and deeper divisions emerged when the secessionist rebels were unable to control the situation after the PNG forces withdrew from Bougainville in March 1990.

The local democratic forces to which autonomy had given rise were as much the victims of the anger and violence of the rebels as of the central authorities. The 1976 devolution arrangements had strengthened Bougainville's links to the rest of the country, for they eliminated some genuine grievances and established a democratic order internally connected to the national system. There is little doubt that, without the 1976 autonomy, the rebellion of 1989 would have garnered more support in Bougainville. Hence autonomy limited support for secession rather than promoted it. In presenting its case for greater autonomy in the 1999-2001 negotiations, the potential of autonomy to strengthen national unity by producing a better balance between national and provincial interests was highlighted by some Bougainvillean negotiators.

The key to the settlement was the promise not so much of independence but the willingness of PNG to consider it - in effect, the postponement of this critical issue. The 2001 agreement represents a departure (albeit reluctant on the part of the national government) from obsession with state sovereignty. It not only diffused the 
sovereignty issue by hinting at the coordinate status of Bougainville with PNG, but also fudged that issue by postponing resolution of the ambiguity. Diffusing, fragmenting and fudging sovereignty will probably also be critical to the settlement of many internal disputes as the 2001 agreement is implemented. Sovereignty also becomes contingent, depending on circumstances beyond the control of the central state; in some situations it has to be earned. We have examples of this same phenomenon from New Caledonia, ${ }^{7}$ where a peace agreement makes provision for a combination of autonomy and a deferred referendum on independence. Serious negotiations over Bougainville started only when it was agreed (even though, initially, only hypothetically on the part of the national government) that independence could in some sense be part of the agenda.

There are, however, risks for PNG in arrangements that keep open the possibility of independence for Bougainville. On the one hand, they create pressure on PNG to allocate high levels of resources to Bougainville (to encourage a majority preintegration vote in the referendum vote). On the other hand, PNG faces severe fiscal problems that make it difficult to treat Bougainville as a special case. Some national government elements expect that a strong pro-independence vote is likely anyway, and so oppose allocating additional funding that they see as likely to build Bougainville capacity for independence. If Bougainvilleans' high expectations of autonomy are not met, frustration can be expected to grow.

There is no doubt that the high level of autonomy now available to Bougainville would enable it to explore the innovative development strategies that many other island autonomies have been deploying (Baldacchino, 2004). Even para-diplomacy is now much more readily open, with the $A B G$ having some foreign affairs-related powers available. But the main examples of island autonomies that have made effective use of such strategies are autonomies arising from a colonial relationship, in which the capacities have developed gradually in a situation where the colonial authority (present or former) has interests in building capacity of and providing resources to the autonomous unit. These experiences may have little relevance to Bougainville, where capacity is low and will be difficult to build, and there are indications of limited interest at the national level in providing high levels of resources. If Bougainvillean expectations about autonomy are not met, then frustration about the operation of autonomy may contribute to growing nationalism and a tendency to assume that a referendum vote for independence is the only option. If so, it may be not so much autonomy that leads to increased pressure for secession but difficulties in managing the agreed arrangements for a combination of autonomy with a deferred referendum on independence.

\section{Acknowledgements}

Yash Ghai thanks the University of Hong Kong for the Distinguished Researcher Award that has supported his research on autonomy systems. Much of the analysis in this chapter derives from Ghai's participation in the preparation of the independence constitution of Papua New Guinea $(1973-75)$ and in negotiations between the national government and Bougainville on their relationship in 1975-76, and from the participation of both Ghai and Regan in the implementation of the devolution package adopted in 1976, and in the 1999-2001 negotiations for the Bougainville Peace Agreement, plus reflections on these experiences. 


\section{Notes}

1. For discussion of the process, see Griffin et al. (1979, pp. 217-229); Wolfers (1982); Ghai (1985; 1988a; 1997); Somare (2001); Momis (2001); Narokobi (2001); and Regan et al. (2001, pp. 345-365).

2. In Papua New Guinea the term decentralization rather than devolution was used. In this chapter we use the term devolution, as it more accurately describes the system that was favoured by the constitutional commission and as it is generally understood.

3. For detailed analysis of the origins and operation of the 1976 devolution arrangements, see Conyers (1976); Barnett (1979); Ballard (1981); Regan (1985a; 1985b); Axline (1986); Ghai and Regan (1992; 2001); May and Regan (1997); and May (1999).

4. For discussion of the origins and course of the conflict, see Filer (1990); May and Spriggs (1990); Ogan (1992); Spriggs and Denoon (1992); Wesley-Smith (1992); Regan (1998a, 2001a, 2003, 2005a); Denoon (2000); Ghai and Regan (2000); Kauona (2001); Regan and Griffin (2005); May (2005).

5. For discussion of the complex origins and unfolding of the peace process, see Regan (1997); Dinnen et al. (1997); Dorney (1998); O'Callaghan (1999); Wehner and Denoon (2001); Rolfe (2001); Adams (2001); Regan (2001a, 2001b, 2002a, 2002b, 2002c, 2003); Carl and Garasu (2002); Boege and Garasu (2004); and May (2005).

6. Agranoff (1994); Boase (1994); Browne-John (1994); Ghai (2002b, pp. 157-162); Milne (1994); and Stevens (1997).

7. See Chappell (1999); Maclellan (1999, 2005); Garde (2001); Angleviel (2003); Faberon (2003); Faberon and Postic (2004); Christnacht (2004); and Rumley (2006).

\section{References}

Adams, R. (Ed.) (2001) Gudpela Nius Bilong Pis. Peace on Bougainville: Truce Monitoring Group (Wellington: Victoria University Press).

Agranoff, J. (1994) Asymmetrical and symmetrical federalisms in Spain: an examination of intergovernmental policy, in B. de Villiers (Ed.), Evaluating Federal Systems (Cape Town: Juta).

Angleviel, F. (2003) The bet on intelligence: politics in New Caledonia, 1988-2002, State, Society and Governance in Melanesia: Discussion Paper (Canberra: SSGM, Australian National University).

Axline, W. (1986) Decentralisation and Development Policy: Provincial Government and the Planning Process in Papua New Guinea, IASER Monograph No. 26 (Waigani: PNG Institute of Applied Social and Economic Research).

Baldacchino, G. (2004) Autonomous but not sovereign? A review of island sub-nationalism, Canadian Review of Studies in Nationalism, 31(1-2), pp. 77-91.

Baldacchino, G. (2006) Innovative development strategies from non-sovereign island jurisdictions? A global review of economic policy and governance practices, World Development, 34(5), pp. 852-867.

Ballard, J. (1981) Policy making as trauma, in Ballard (Ed.), Policy Making in a New State: Papua New Guinea, 1972-1977, pp. 95-132 (St Lucia: University of Queensland Press).

Barnett, T. (1979) Politics and planning rhetoric in Papua New Guinea, Economic Development and Cultural Change, 27(4), pp. 769-784.

Bedford, R. and Mamak, A. (1977) Compensation for Development: The Bougainville Case, Bougainville Special Publication No. 2 (Christchurch: Department of Geography, University of Canterbury).

Boase, J. (1994) Faces of asymmetry: German and Canadian federalism, in B. de Villiers (Ed.), Evaluating Federal Systems (Cape Town: Juta). 
Boege, V. and Garasu, L. (2004) Papua New Guinea: a success story of postconflict peacebuilding in Bougainville, in A. Heijman, N. Simmonds and H. van de Veen (Eds), Searching for Peace in Asia Pacific: An Overview of Conflict Prevention and Peace-building Activities, pp. 564-579 (Boulder, CO: Lynne Rienner).

Bougainville Peace Agreement (2001) Bougainville Peace Agreement, 30 August 2001, Papua New Guinea National Gazette, G 146, 16 November (Port Moresby: Papua New Guinea Government Printer).

Browne-John, L. (1994) Asymmetrical federalism: keeping Canada together?, in B. de Villiers (Ed.), Evaluating Federal Systems, pp. 16-29 (Cape Town: Juta).

Carl, A. and Garasu, L. (Eds) (2002) Weaving Consensus: The Papua New GuineaBougainville Peace Process (London: Conciliation Resources (Accord, Issue 12)).

Chappell, D. (1999) The Noumea Accord: decolonization without independence in New Caledonia?, Pacific Affairs, 72(3), pp. 373-391.

Christnacht, A. (2004) La Nouvelle-Calédonie (Paris: Documentation Française).

Connell, J. (1991) Compensation and conflict: the Bougainville copper mine, Papua New Guinea, in J. Connell and R. Howitt (Eds), Mining and Indigenous Peoples in Australasia, pp. 55-76 (Sydney: Sydney University Press).

Conyers, D. (1976) The Provincial Government Debate: Central Control Versus Local Participation in Papua New Guinea, IASER Monograph No. 2 (Waigani: PNG Institute of Applied Social and Economic Research).

CPC (1974) Final Report of the Constitutional Planning Committee, Parts 1 and 2 (Port Moresby: PNG Government).

Denoon, D. (2000) Getting Under the Skin: The Bougainville Copper Agreement and the Creation of the Panguna Mine (Melbourne: Melbourne University Press).

Dinnen, S., May, R. and Regan, A. (Eds) (1997) Challenging the State: The Sandline Affair in Papua New Guinea (Canberra: Asia-Pacific Press, National Centre for Development Studies, Australian National University).

Dorney, S. (1998) The Sandline Affair: Politics and Mercenaries and the Bougainville Crisis (Sydney: ABC Books).

Faberon, J. (2003) La Nouvelle-Calédonie et la révision constitutionelle de mars 2003 sur l'organisation décentralisée de la république, Revue juridique, politique et économique de Nouvelle-Calédonie, 1 , pp. 3-7.

Faberon, J. and Postic, J. (2004) L'Accord de Noumea, la loi organique et autres documents juridiques et politiques de la Nouvelle-Calédonie (Noumea: Île de Lumière).

Filer, C. (1990) The Bougainville rebellion, the mining industry and the process of social disintegration in Papua New Guinea, in R. May and M. Spriggs (Eds), The Bougainville Crisis, pp. 112-140 (Bathurst: Crawford House Press).

Garde, F. (2001) Les Institutions de la Nouvelle Caledonie (Paris: L'Harmattan).

Ghai, Y. (1985) Land regimes and paradigms of development: reflections on Melanesian constitutions, International Journal of the Sociology of Law, 13(2), pp. 393-405.

Ghai, Y. (1988a) Constitution making and decolonisation, in Y. Ghai (Ed.), Law, Government and Politics in the Pacific Island States, pp. 1-53 (Suva: Institute of Pacific Studies, University of the South Pacific).

Ghai, Y. (1988b) Political consequences of constitutions, in Y. Ghai (Ed.), Law, Government and Politics in the Pacific Island States, pp. 350-372 (Suva: Institute of Pacific Studies, University of the South Pacific).

Ghai Y. (1997) Securing a liberal democratic order through a constitution: the case of Papua New Guinea, Development and Change, 28(2), pp. 303-330.

Ghai, Y. (2000) Ethnicity and autonomy: a framework for analysis, in Ghai (Ed.), Autonomy and Ethnicity: Negotiating Competing Claims in Multi-etbric States, pp. 242-265 (Cambridge: Cambridge University Press). 
Ghai, Y. (2002a) Global prospects of autonomies, in H. Jansson and J. Salminen (Eds), The Second Åland Islands Question: Autonomy or Independence?, pp. 29-54 (Mariehamn: Julius Sundblom Memorial Foundation).

Ghai, Y. (2002b) Constitutional asymmetries: communal representation, federalism and cultural autonomy, in A. Reynolds (Ed.), The Architecture of Democracy: Constitutional Design, Conflict Management and Democracy, pp. 157-162 (Oxford: Oxford University Press).

Ghai, Y. and Regan, A. (1992) Law, Politics and Administration of Decentralisation in Papua New Guinea (Port Moresby: PNG NRI).

Ghai, Y. and Regan, A. (2000) Bougainville and the dialectics of ethnicity, autonomy and separation, in Y. Ghai (Ed.), Autonomy and Ethnicity: Negotiating Competing Claims in Multi-Ethnic States, pp. 242-265 (Cambridge: Cambridge University Press).

Ghai, Y. and Regan, A. (2001) Decentralisation: 1976-1995, in A. Regan, O. Jessup and E. Kwa (Eds), Twenty Years of the Papua New Guinea Constitution, pp. 161-180 (Sydney: Law Book Co.).

Griffin, J. (1972) Bougainville: secession or just sentiment?, Current Affairs Bulletin, 48(9), pp. 259-280.

Griffin, J. (1973) Buka and Arawa: some black thoughts on a white history of Bougainville, Meanjin Quarterly, 32(4), pp. 452-456.

Griffin, J. and Togolo, M. (1997) North Solomons Province, in R. May and A. Regan (Eds), Political Decentralisation in a New State: The Experience of Provincial Government in Papua New Guinea, pp. 354-382 (Bathurst: Crawford House Publishing).

Griffin, J., Nelson, H. and Firth, S. (1979) Papua New Guinea: A Political History (Melbourne: Heinemann Educational).

Kauona, S. (2001) Freedom from fear, in R. Adams (Ed.), Gudpela Nius Bilong Pis. Peace on Bougainville: Truce Monitoring Group, pp. 84-94 (Wellington: Victoria University Press).

Larmour, P. (1990) Ethnicity and decentralisation in Melanesia: a review of the 1980s, Pacific Viewpoint, 31(2), pp. 10-27.

Larmour, P. (1992) The politics of race and ethnicity: theoretical perspectives on Papua New Guinea, Pacific Studies, 15(2), pp. 87-108.

McElroy, J. and Mahoney, M. (1999) The propensity for political dependence in island microstates, Insula: International Journal of Island Affairs, 9(1), pp. 32-35.

Maclellan, N. (1999) The Noumea Accord and decolonisation in New Caledonia, Journal of Pacific History, 34(3), pp. 245-252.

Maclellan, N. (2005) From Elois to Europe: interactions with the ballot box in New Caledonia, Journal of Commonwealth and Comparative Politics, 43(3), pp. 394-418.

Mamak, A. and Bedford, R. (1974) Bougainvillean Nationalism: Aspects of Unity and Discord, Bougainville Special Publication No. 1 (Christchurch: Department of Geography, University of Canterbury).

May, R. (Ed.) (1982) Micronationalist Movements in Papua New Guinea, Political and Social Change Monograph No. 1 (Canberra: Australian National University).

May, R. (1997) Postscript: the Organic Law on Provincial Governments and Local-Level Governments, in R. May and A. Regan (Eds), Political Decentralisation in a New State: The Experience of Provincial Government in Papua New Guinea, pp. 386-395 (Bathurst: Crawford House Publishing).

May, R. (1999) Decentralization in Papua New Guinea: two steps forward, one step back, in M. Turner (Ed.), Central-Local Relations in Asia Pacific: Convergence or Divergence?, pp. 123-148 (London: Macmillan).

May, R. (2005) The Bougainville conflict and its resolution, in J. Henderson and G. Watson (Eds), Securing a Peaceful Pacific, pp. 459-469 (Christchurch: University of Canterbury Press).

May, R. and Regan, A. (Eds) (1997) Political Decentralisation in a New State: The Experience of Provincial Government in Papua New Guinea (Bathurst: Crawford House Publishing). 
May, R. and Spriggs, M. (Eds) (1990) The Bougainville Crisis (Bathurst: Crawford House Press).

Milne, D. (1994) Exposed to the glare: constitutional camouflage and the fate of Canada's federation, in E. Seidle (Ed.), Seeking a New Canadian Partnership: Asymmetrical and Confederal Options (Ottawa: Institute for Research on Public Policy).

Momis, J. (2001) The constitutional planning committee and the constitution, in A. Regan, O. Jessup and E. Kwa (Eds), Twenty Years of the Papua New Guinea Constitution, pp. 1924 (Sydney: Law Book Co.).

Momis, J. (2005) Shaping leadership through Bougainville indigenous values and Catholic seminary training: a personal journey, in A. Regan and H. Griffin (Eds), Bougainville before the Conflict, pp. 300-316 (Canberra: Pandanus Press).

Narokobi, B. (2001) The constitutional planning committee, nationalism and vision, in A. Regan, O. Jessup and E. Kwa (Eds), Twenty Years of the Papua New Guinea Constitution, pp. 25-32 (Sydney: Law Book Co.).

Nash, J. (2001) Paternalism, progress, paranoia: patrol reports and colonial history in south Bougainville, in N. McPherson (Ed.), In Colonial Papua New Guinea: Anthropological Perspectives, pp. 111-124 (Pittsburgh, PA: University of Pittsburgh Press).

Nash, J. and Ogan, E. (1990) The red and the black: Bougainville perceptions of other Papua New Guineans, Pacific Studies, 13(2), pp. 1-17.

O'Callaghan, M. (1999) Enemies Within. Papua New Guinea, Australia and the Sandline Crisis: The Inside Story (Sydney: Doubleday).

Ogan, E. (1992) The cultural background to the Bougainville crisis, Journal de la Société des Océanistes, 92-93, pp. 61-67.

Ogan, E. (1996) Copra came before copper: the Nasioi of Bougainville and plantation colonialism 1902-1964, Pacific Studies, 19(1), pp. 31-51.

Oliver, D. (1991) Black Islanders: A Personal Perspective of Bougainville 1937-1991 (Melbourne: Hyland House).

Quodling, P. (1991) Bougainville: The Mine and the People (St Leonards, NSW: Centre for Independent Studies).

Premdas, R. (1998) Secession and decentralization: the Bougainville case, Canadian Review of Studies in Nationalism, 25(1), pp. 23-36.

Regan, A. (1985a) Papua New Guinea (b): implementing provincial government, in P. Larmour and R. Qalo (Eds), Decentralisation in the South Pacific - Local, Provincial and State Government in Twenty Countries, pp. 119-154 (Suva: University of the South Pacific).

Regan, A. (1985b) Papua New Guinea (c): national-provincial relations, in P. Larmour and R. Qalo (Eds), Decentralisation in the South Pacific - Local, Provincial and State Government in Twenty Countries, pp. 155-171 (Suva: University of the South Pacific).

Regan, A. (1997) Preparation for war and progress towards peace: Bougainville dimensions of the Sandline affair, in S. Dinnen, R. May and A. Regan (Eds), Challenging the State: The Papua New Guinea Sandline Affair, pp. 82-93 (Canberra: NCDS, Australian National University).

Regan, A. (1998a) Causes and course of the Bougainville conflict, Journal of Pacific History, 33(3), pp. 269-285.

Regan A. (1998b) Case study: Bougainville, in P. Harris and B. Reilly (Eds), Democracy and Deep-rooted Conflict: Options for Negotiators, pp. 171-178 (Stockholm: International Institute for Democracy and Electoral Assistance).

Regan, A. (2001a) Why a neutral peace monitoring force? The Bougainville conflict and the peace process, in M. Wehner and D. Denoon (Eds), Without a Gun: Australia's Experience of Monitoring Peace in Bougainville, 1997-2001, pp. 1-18 (Canberra: Pandanus Books).

Regan, A. (2001b) Establishing the truce monitoring group and the peace monitoring group, in M. Wehner and D. Denoon (Eds), Without a Gun: Australia's Experience of Monitoring Peace in Bougainville, 1997-2001, pp. 19-40 (Canberra: Pandanus Books). 
Regan, A. (2002a) The Bougainville political settlement and the prospects for sustainable peace, Pacific Economic Bulletin, 17(1), pp. 114-129.

Regan, A. (2002b) Bougainville: beyond survival, Cultural Survival Quarterly, 26(3), pp. 20 24.

Regan, A. (2002c) Resolving two dimensions of conflict and division: the dynamics of consent, consensus and compromise, in A. Carl and L. Garasu (Eds), Accord: Weaving Consensus The Papua New Guinea-Bougainville Peace Process, 12, pp. $36-43$ (London: Conciliation Resources).

Regan, A. (2003) The Bougainville conflict: political and economic agendas, in K. Ballentein and J. Sherman (Eds), The Political Economy of Armed Conflict: Beyond Greed o Grievance, pp. 133-166 (Boulder, CO: Lynne Rienner).

Regan, A. (2005a) Clever people solving difficult problems: perspectives on weakness of the state and nation in Papua New Guinea, Development Studies Bulletin, 67(April), pp. 6-12.

Regan, A. (2005b) Identities among Bougainvilleans, in A. Regan and H. M. Griffin (Eds), Bougainville before the Conflict (Canberra: Pandanus Press).

Regan, A. and Griffin, H.M. (Eds), Bougainville before the conflict (Canberra: Pandanus Press).

Regan, A., Jessup, O. and Kwa, E. (2001) Transcript of panel discussion - panel of constitution-maker, in Regan et al. (Eds), Twenty Years of the Papua New Guinea Constitution, pp. 345-365 (Sydney: Law Book Co.).

Rolfe, J. (2001) Peacekeeping the Pacific way in Bougainville, International Peacekeeping, 12(4), pp. 599-608.

Rumley, D. (2006) The French geopolitical project in New Caledonia, in D. Rumley, V. Forbes and C. Griffin (Eds), Australia's Arc of Instability: The Political and Cultural Dynamics of Regional Security, pp. 229-246 (Dordrecht: Springer).

Somare, M. (2001) Reflections on constitution-making, in A. Regan, O. Jessup and E. Kwa (Eds), Twenty Years of the Papua New Guinea Constitution, pp. 15-18 (Sydney: Law Book Co.).

Spriggs, M. and Denoon, D. (Eds) (1992) The Bougainville Crisis: 1991 Update (Canberra: Australian National University in association with Crawford House Press).

Stevens, R. (1997) Asymmetrical federalism: the federal principle and the survival of small republics, Publius: Journal of Federalism, $7(4)$ (special issue on 'Federalism and Identity', ed. Ivo D. Duchacek), pp. 117-203.

Tanis, J. (2005) Nagovisi villages as a window on Bougainville in 1988, in A. Regan and H. M. Griffin (Eds), Bougainville before the Conflict, pp. 447-472 (Canberra: Pandanus Press).

Togolo, M. (2005) Torau response to change, in A. Regan and H. M. Griffin (Eds), Bougainville before the Conflict, pp. 274-290 (Canberra: Pandanus Press).

Tordoff, W. and Watts, R. (1974) Report on central-provincial government relations, mimeo, Port Moresby.

Tryon, D. (2005) The languages of Bougainville, in A. Regan and H. M. Griffin (Eds), Bougainville before the Conflict, pp. 31-46 (Canberra: Pandanus Press).

Watts, R. (1999) Comparing Federal Systems (Montreal and Kingston: McGill-Queen's University Press).

Wehner, M. and Denoon, D. (2001) Without a Gun: Australia's Experience of Monitoring Peace in Bougainville, 1997-2001 (Canberra: Pandanus Books).

Wesley-Smith, T. (1992) Development and crisis in Bougainville: a bibliographic essay, Contemporary Pacific, 4(2), pp. 408-432.

Wolfers, E. (1982) Aspects of political culture and institution building in Melanesia: the Constitutional Planning Committee in Papua New Guinea and the Special Committee on Provincial Government in Solomon Islands, Pacific Studies, 6(1), pp. 85-108.

Wolfers, E., Conyers, D., Larmour, P. and Ghai, Y. (1982) Manual on Decentralisation (London: Commonwealth Secretariat). 